\title{
THE HistORY AND RECONSTRUCTION OF THE AMBER ROOM
}

Russell Shor

The Amber Room was constructed for King Frederick I of Prussia in Danzig (modern-day Gdansk, Poland) between 1701 and 1714. The amber panels making up the room were presented to Czar Peter I of Russia in 1716 and eventually installed in the Catherine Palace near St. Petersburg. They remained there until the outbreak of World War II, when a German army unit looted the room. The Soviet government, which deemed the room a cultural treasure, mandated its reconstruction in 1979, beginning a 24-year process that culminated with its reopening in 2003. This article offers a history of the original room drawn from the published writings of historians, accounts of the looting and subsequent disappearance of the amber panels, and detailed firsthand accounts of the reconstruction from those who participated in its planning, design, and execution.

T he Amber Room (figure 1), located in the Catherine Palace in the Russian town of Pushkin (previously Tsarskoye Selo), is considered by many historians the pinnacle of amber craftsmanship. The chamber is a reconstruction of the first Amber Room, which was begun in 1701 by order of Frederick I of Prussia and was actually a series of large panels designed to be mounted onto walls within Berlin's Charlottenburg Palace. The original project took 13 years to complete. Once it was finished, Frederick's son, William I, presented the amber panels to Peter the Great of Russia to commemorate a treaty between the two rulers against Charles XII of Sweden. The panels were installed in the Winter Palace in St. Petersburg and in 1755 moved to the Catherine Palace, where they remained for nearly 200 years.

In 1941, Nazi Germany invaded Russia. After surrounding St. Petersburg (called Leningrad between 1924 and 1991), they occupied Pushkin. Just before the invaders reached the palace, its caretakers removed the smaller amber objects from the Amber Room and attempted to hide the panels behind wallpaper. The invading German officers, however, knew of the room and confiscated the panels before destroying most of the palace. After the war, the panels were never seen again.

See end of article for About the Author and Acknowledgments.

Gems \& Gemology, Vol. 54, No. 2, pp. 378-393,

http://dx.doi.org/10.5741/GEMS.54.4.393

(C) 2018 Gemological Institute of America
In 1979, Russian craftsmen began the long process of recreating the Amber Room. This was extremely challenging because there was little documentation of the original room. Many of the amber working skills of the eighteenth-century craftsmen had been lost, and the materials used in adhesives and dyes were no longer known. With the work less than half

\section{In Brief}

- The original Amber Room panels were constructed in Prussia from 1701 to 1714 , presented to Peter the Great of Russia, and installed in the Catherine Palace.

- The panels were looted by the advancing German army in 1941 and are presumed lost.

- Reconstruction began in 1979, but there was scant photographic evidence of the original room and little documentation of the materials and techniques used.

- After 24 years of work, the craftsmen in the amber studio achieved an accurate reconstruction of the room.

completed, political changes nearly forced the project's end. From initial research to the reopening of the room before heads of state in 2003, the reconstruction took 24 years to complete.

\section{BALTIC AMBER}

Baltic amber, or succinate, is fossilized resin from Pinus succinifera. This tree grew in abundance 


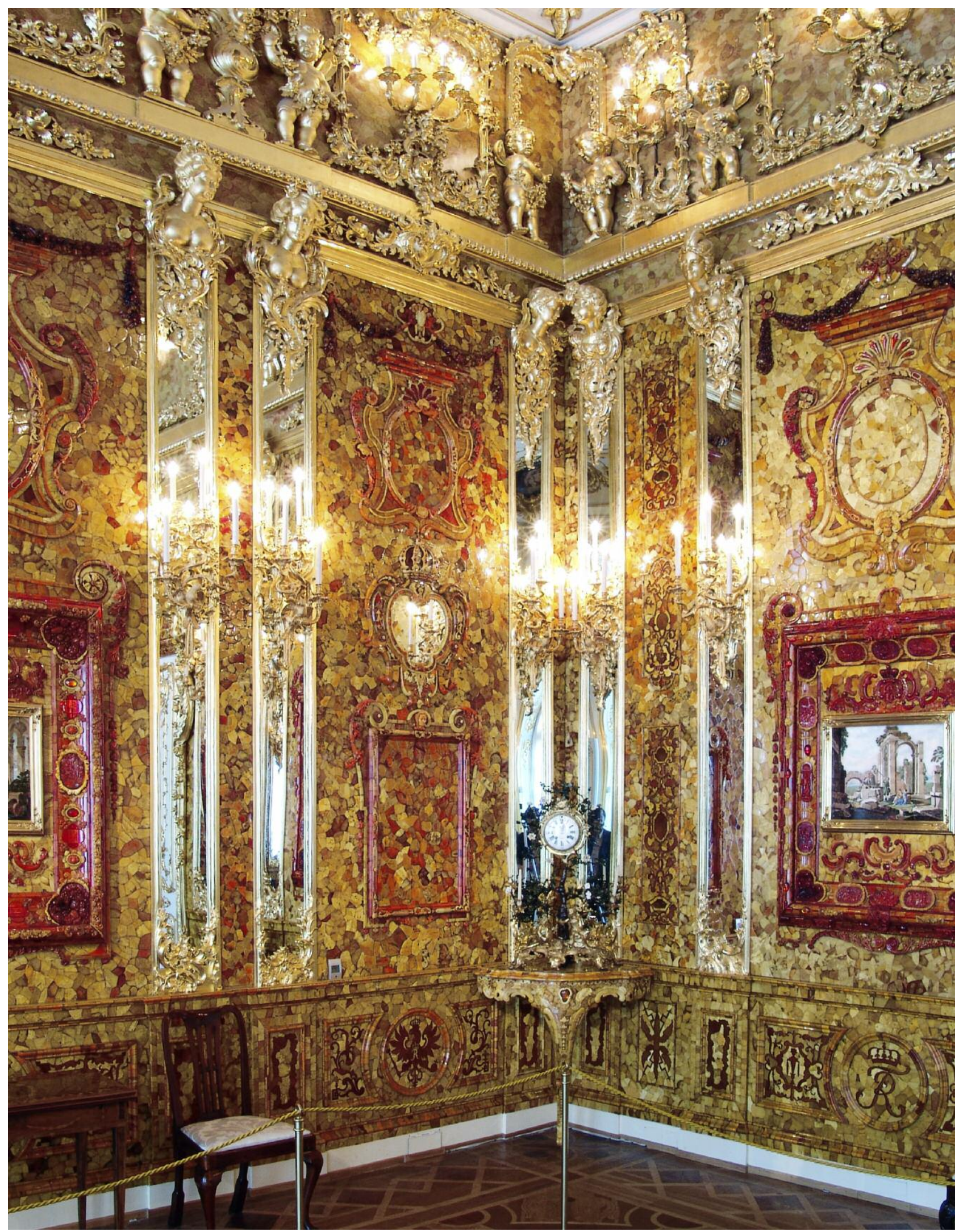

Figure 1. Detail showing the upper portions of the reconstructed room, including the gilded sculptures and the imitation amber painting above the cornice. Photo courtesy of Amberif. 
throughout Scandinavia and northern Europe more than 20 million years ago (Kosmowska-Ceranowicz, 2009). The vast Baltic area deposits were formed when resin-bearing sediments flowed from Scandinavia to the Sambia Peninsula (figure 2), transforming those resins over millions of years into amber. Streams and rivers and glaciers carried large amounts of amber throughout northern Europe as secondary deposits (Gaigalas and Salas, 2009). The primary deposits of the southern Baltic region-particularly the Sambia Peninsula, where Kaliningrad, Russia, is situated-are the world's most prolific sources of amber and among the oldest gem deposits still in production, dating back to before recorded history. While there are no ancient accounts of amber mining, most of the material was probably collected on beaches following storms - a method still used today by amateur collectors. Amber objects and carvings dating back to prehistoric times have been found in Great Britain (9000 BCE) and in the southern Baltic region (6000 BCE) (Langenheim, 1990).

\section{THE AMBER ROADS}

Collection and trade of amber in the Baltic region for ornamental uses is believed to have begun some 6,000 years ago, during the Neolithic period. Amber was regarded as a valuable trading commodity for its deco-

Figure 2. The southern Baltic region and Sambia Peninsula are the source of a vast amber deposit that has been producing since before recorded history. The most prolific area of the deposit is located near Kaliningrad. The city of Danzig (now Gdansk) on the western portion of the map has been a center of amber craftsmanship for more than 1,000 years and was the home of the designers and builders of the original Amber Room.

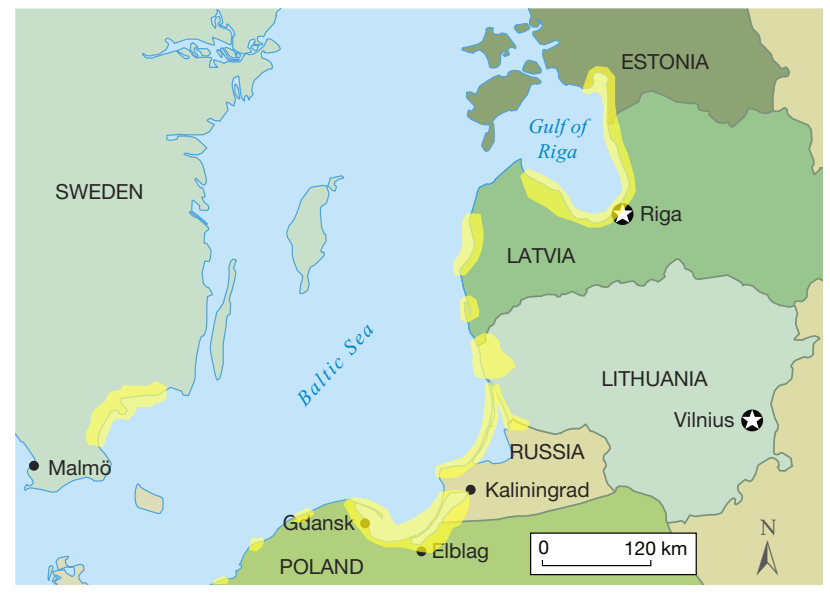

rative qualities and for its use as fuel for fires. Amber trade routes extended from the Baltic through the continent to southern Europe and the Arabian Peninsula; some routes dating back to the Neolithic have been documented (Butrimas and Jovaiša, 2013). Among the best documented were the amber trade routes extending from the Baltic Sea to the Mediterranean. These were established around $3000 \mathrm{BCE}$, based on archeological finds of beads and carvings in various locations in Eastern Europe (Mazurowski, 2011). In addition, a trove of 850 amber ornaments, estimated to have been created about $3000 \mathrm{BCE}$, were found in present-day Lithuania, and evidence of an amber carving enterprise was discovered in what is now Latvia (Grimaldi, 1996; Czebreszuk and Szmyt, 2013).

Amber's origins were known by the first century CE. Pliny the Elder, a contemporary of Roman Emperor Nero (37-68 CE), wrote in Natural History that the material "is formed from the liquid that exudes from a type of pine tree" but noted it was generally useless except as an adornment for women (Clark, 2010). The Roman historian Tacitus described the trading of Baltic amber with Germanic tribes that collected and bartered the material (Clark, 2010). Pliny noted the high value Romans placed on amber and wrote that Nero's chief gladiator, Julian, dispatched a mission to the north to bring back large quantities of it. Upon their return, the Romans used the amber to decorate the arena for gladiator games. Because it was believed to have protective qualities, the material was sewn into the nets separating the spectators from the wild animals in the area.

Trade routes originated at the southern Baltic coast near the site where Danzig (now Gdansk, Poland) was founded. The best-known route was down the Vistula River and over land to the Danube, to the Roman port of Aquileia on the Adriatic Sea. This was generally known as the Amber Road. However, archaeological evidence indicates many socalled Amber Roads that wound through Europe, all leading from Danzig or Königsberg (now Kaliningrad), about $120 \mathrm{~km}$ (75 miles) east from Danzig, to Aquileia, or ports on the Mediterranean as far west as Massalia (now Marseille; Clark, 2010).

One of the most important amber trading centers was the Viking village of Truso, located near the modern-day city of Elblag in Poland. Excavations conducted over the past 120 years have found remains of amber workshops and objects from Viking and Celtic civilizations (Mazurowski, 2011). By the time Danzig, about approximately $60 \mathrm{~km}$ (37 miles) from Truso, was founded around 980, amber working 


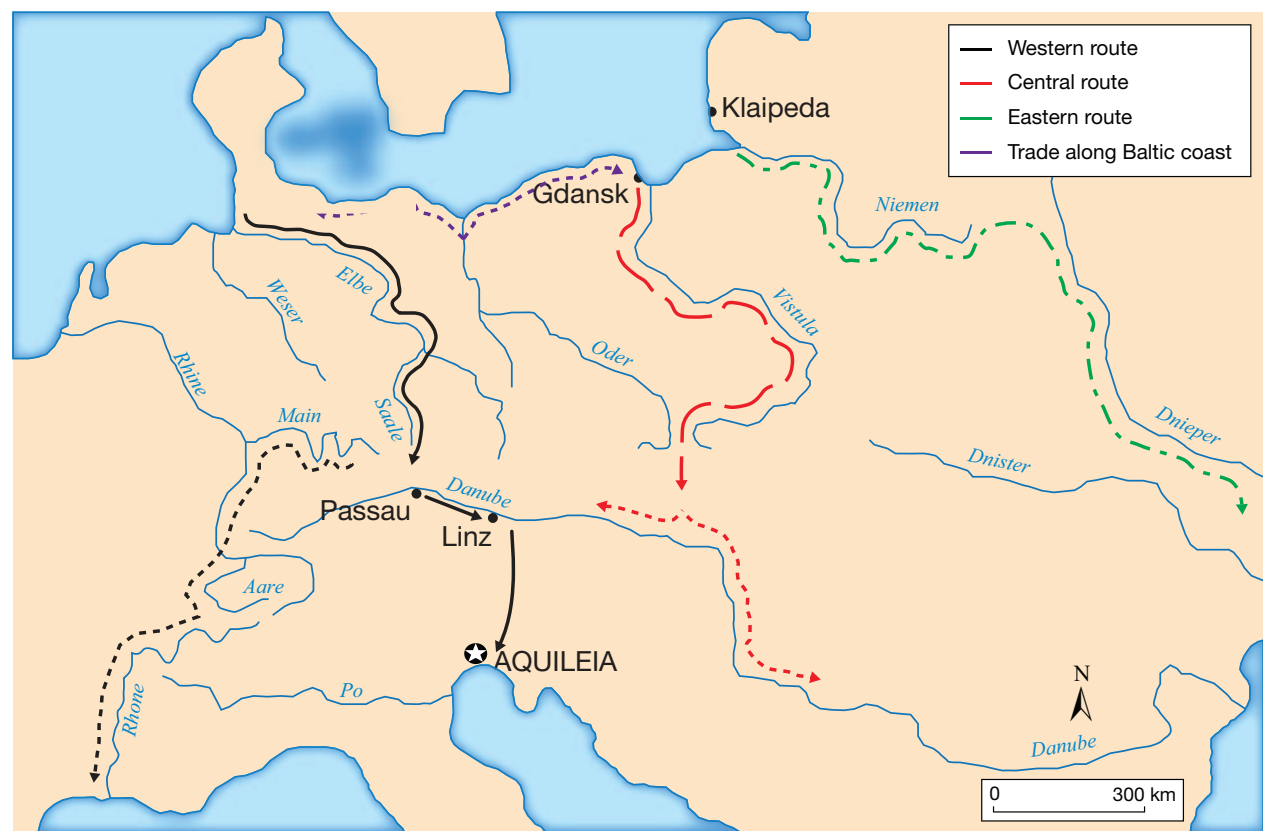

Figure 3. Amber has been collected and traded throughout Europe and as far as the Middle East for at least 6,000 years. Archaeological finds show a number of early trade routes from the Baltic to the Adriatic and Mediterranean Seas; these roads were highly developed by the time of ancient Greece and Rome.

was a recognized skill among its inhabitants (City of Gdansk, 2017; see figure 3).

Up to this point, most amber had been collected by Baltic tribes inhabiting the southern coastal areas and the Sambia Peninsula. After the religious order known as the Teutonic Knights returned from the Crusades in 1211, the Duke of Masovia (which encompassed modern-day Warsaw) enlisted their help in conquering the tribes. The Knights completed their conquest of the Balts in 1283 and in 1312 assumed a monopoly over the amber trade, even forbidding its collection on the beaches. Despite the restrictions, amber remained a widely traded commodity in the southern Baltic region in the Prussian states, especially between Danzig and other cities that were members of the Hanseatic League, a Baltic-centered trading alliance (Grimaldi, 1996). Because of the Knights' iron rule over trade in the region, craft guilds specializing in amber formed in cities outside their jurisdiction, even as far away as Bruges, Belgium, where craftsmen carved the material into rosaries (Grimaldi, 1996).

By the end of the fifteenth century, the Knights' centuries-long grip over amber mining and trade had weakened. In 1533, the Duke of Prussia granted control over much of the raw amber supply to a syndicate of traders led by Paul Koehn von Jaski. This syndicate established workshops in Livorno, Italy, Vienna, Berlin, Paris, and Persia, and their monopoly endured until 1642 (Netzer, 1993). As supply increased and trade became freer, amber workers formed guilds. The first was in Danzig in 1477, followed by Stolp (now Słupsk) and Kolberg (now Kołobrzeg), both in 1480
(Netzer, 1993). The Danzig guild produced mainly religious items such as altars, shrines, and images of saints. The others created an array of amber goods: small furniture pieces, game boards, mythological figures, lidded tankards, and decorative objects (Grimaldi, 1996). The Königsberg guild was founded much later (1641), when the elector of Brandenburg permitted it to set up in his residence (Netzer, 1993).

Through the guilds, amber craftsmanship evolved to a high art in Prussia over the following two centuries. Workshops developed techniques beyond carving to create large furniture pieces, sculptures, and other commissions from the Brandenburg Court, which ruled the region from 1618 to 1701 . By the end of the seventeenth century, many prominent amber craftsmen had assembled in Danzig and Königsberg because the Brandenburg Court had begun commissioning major amber works as gifts to foreign rulers to seal diplomatic pacts (Netzer, 1993). One of the most renowned workshops in Danzig, where many such works were made, was operated by the head of the guild, Gottfried Turau, and his partner, Ernst Schacht. These men would figure prominently in the construction of the Amber Room (Grimaldi, 1996).

\section{THE ORIGINAL AMBER ROOM}

The idea of the Amber Room was first raised by Frederick III, elector of Brandenburg, then a principality within the Holy Roman Empire and today a province that surrounds Berlin. Frederick III (later Frederick I of Prussia) inherited the title of elector in 1688 at the same time he was named Duke of 


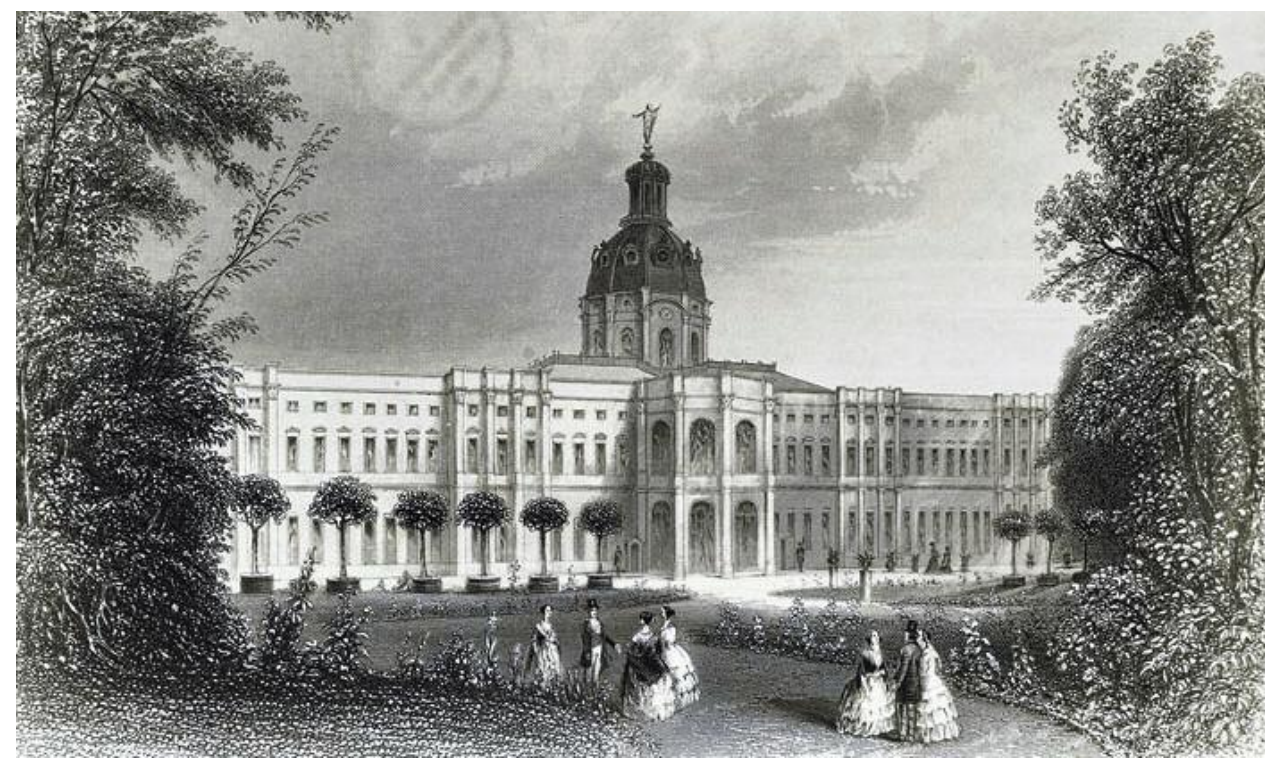

Figure 4. The Amber Room was designed for a chamber in the Charlottenburg Palace in Berlin but was never housed there. Courtesy of Tsarskoye Selo Amber Workshop.

Prussia, which encompassed the southern Baltic coast and the Sambia Peninsula. During this period, Frederick commissioned three large mirror frames made from natural-color and dyed amber with ivory accents. The mirrors measured $142 \times 120 \mathrm{~cm}, 156 \times$ $116 \mathrm{~cm}$, and $156 \times 116 \mathrm{~cm}$ at their outer dimensions, and each frame was $13 \mathrm{~cm}$ wide (Gierlowski, 2006a). These mirror frames would be incorporated into the Amber Room during its construction some 20 years later.

Upon his elevation to King of Prussia in 1701, Frederick decided to commemorate his rule by creating a room fully lined with amber in the Charlottenburg Palace in Berlin (figure 4). That room, he believed, would surpass the opulence of Louis XIV's palace at Versailles (Gierlowski, 2006a).

At that time, large stocks of uncut amber, including many very large pieces, had accumulated in warehouses in Danzig, about $480 \mathrm{~km}$ (300 miles) east of Berlin. The excess supplies were a result of increased mining activities in the Sambia Peninsula and the Curonian Spit, a sand barrier separating Königsberg from the Baltic Sea (Grimaldi, 1996).

To design the room, the monarch appointed Andreas Schlüter, director of royal construction in Danzig and one of the architects of the City Palace in Berlin. He selected a cabinet room meant for Frederick I's private audiences, located in a corner of the palace. The room measured more than 74.25 square meters and stood about 5 meters high from floor to ceiling (Gierlowski, 2006a).

The plan was to create the appearance of amber walls through a series of large wood-backed mosaic panels, on which were glued amber slices of varied hues. The design called for 12 main panels measuring over 3.5 meters high, with most nearly $56 \mathrm{~cm}$ wide. Several narrower panels, each approximately $25 \mathrm{~cm}$ wide, were fitted near the corners and windows. Each panel was separated by mirrored pilasters decorated with candelabras and gilded wood carvings. Below the main panels were wainscot panels of equal width, approximately three feet high and separated from the main pieces by a chair rail, also made from assembled amber pieces, and supported by a plinth all the way around. The design called for the craftsmen to add bas-relief decorative elements such as frames, wreaths, and garlands to the amber mosaic panels. The completed panels would then be mounted on the walls. Other decorative elements carved from amber, including garlands, fruit clusters, and sculptured figures carved from wood and gilded with gold foil, would then be mounted on top of the panels. Mounted on the cornice around the room, just below the ceiling, was a series of carved amber pieces with rose, tulip, and other motifs, approximately 20 to 25 $\mathrm{cm}$ high. The design called for the completed amber works to cover $80 \%$ of the wall surface (Gierlowski, 2006a; Owen, 2009).

In addition, there were to be large mirrors on each of the four walls surrounded by the amber frames manufactured in Dresden 25 years earlier. These mirrors would be replaced by stone mosaics after the panels were relocated to the Catherine Palace.

The task of executing the design fell to Gottfried Wolfram, who had worked in the Danish court as a master amber and ivory carver and was renowned for 
his skill in executing intricate, artistic designs. In 1701, Frederick IV of Denmark recommended Wolfram to Frederick I of Prussia to supervise the work (Hein, 1991). In constructing the panels, Wolfram first lined the oak panels with bronze foil, having discovered when making amber-covered furniture that the subtle expansion and contraction of wood due to temperature and humidity caused the amber to crack, fall off, or separate (Gierlowski, 2006a). The slightly reflective bronze backing also enhanced the color of the translucent amber. Wolfram's workmen laid the large oak panels flat and fastened bronze foil to them using iron clasps. They prepared the pieces of amber by sawing them into strips, approximately $5 \mathrm{~mm}$ thick, to be mounted in a mosaic onto the bronze foil (Gierlowski, 2006a).

The adhesive was a mixture of pine resin and beeswax with a low melting point so craftsmen could easily remove or replace broken or ill-fitting slices. The amber carvings were assembled by mortise-andtenon joints (similar to tongue and groove) and fixed to the panel by ivory pegs. The design elements on the main wall panels, cartouches, and cameos and the Dresden frames for the four mirrors were also made of amber and attached by either method. The frames also served as a structural element to strengthen the panels.

After six years, Wolfram's shop had completed onefourth of the panels, frames, and carvings. In 1707, however, Schlüter fell out of favor with the court and was abruptly dismissed from his post, with the captain of the guards, Eosander von Goethe, appointed in his place. In turn, Goethe dismissed Wolfram over a payment dispute and ordered the guards to remove the amber panels and carvings from his workshops-barring Wolfram in the process-and transport everything to Charlottenburg. Wolfram spent a number of years trying to recover his workshop and payment, but he eventually fled to Copenhagen after being threatened with arrest (Hein, 1991; Gierlowski, 2006a).

Schlüter also left Prussia for Saxony and eventually moved to St. Petersburg at the invitation of Peter the Great. Goethe did not modify Schlüter's original design and eventually hired Gottfried Turau and Ernst Schacht to complete the project. An inventory taken six years later, in 1713, indicated that the two craftsmen had completed a majority of the carvings, four of the 12 pilasters, and most of the panels that would cover about $95 \%$ of the walls in the room (Gierlowski, 2006a).

The death of Frederick I in 1713 brought his successor to the Prussian throne. Frederick William I disdained the extravagance the Amber Room represented and promptly ordered all work on it to stop, with the materials packed up and deposited in the Berlin armory. The new monarch also halted payments to Turau and Schacht (Gierlowski, 2006a). The panels and carvings remained hidden in the Berlin armory until 1716, after a visit to the Prussian court by Czar Peter I. Frederick William I took the occasion to present the still-unfinished panels to the Russian monarch in exchange for a company of 40 grenadiers, on November 17, 1716. The exchange sealed a valuable alliance of the two states to end Swedish occupation of large sections of Russia's Baltic coast.

The presentation of the amber panels to Peter I was not an impulsive decision. Prussian royalty had regarded amber as their national treasure for at least a century and had established a tradition of sealing diplomatic agreements with objects such as furniture pieces, chandeliers, and large mirror frames fashioned from the material. The panels for the Amber Room were the largest such gifts (Netzer, 1993). On January 13, 1717, workmen packed the pieces into eight large crates and dispatched them to St. Petersburg. The journey proceeded by road through Königsberg and Klaipeda (in modern-day Lithuania) and took nearly six months. A report from Alexander Menshikov, St. Petersburg's first governor general, noted that "there was practically no damage to the amber cabinet" (Gierlowski, 2006a).

After the shipment's arrival in St. Petersburg, it was discovered that the amber panels, which had been designed for a specific cabinet room in the Charlottenburg Palace, did not conform to any rooms in the Russian palace. Several panels remained unfinished, as did the mirrored pilasters, and no local craftsmen had the skills to complete them and mount the elements to the walls. Neither Peter I, who died in 1725, nor his wife Catherine (r. 1725-7) or grandson Peter II (r. 1727-30) made any decision about where to install the amber panels.

After the death of Peter I, his daughter, Elizabeth, in 1730 ordered the large panels to be displayed in the St. Petersburg Summer Palace, where they remained propped against the walls in various function rooms for 13 years. In 1743, Elizabeth, who had taken the throne two years earlier, ordered her staff to transport the amber elements to the much larger third Winter Palace. She appointed Italian craftsman Alexander Martelli to oversee the mounting of the amber panels in a suitable room. Martelli, who served the Russian court as a monument conservator, also had some skill 
in amber working and the techniques employed by the original Danzig craftsmen (Gierlowski, 2006a). Francesco Bartolomeo Rastrelli, senior court architect, was appointed to redesign the amber elements to fit the new room, which was a much larger ceremonial hall. Other problems presented themselves. When Martelli's workers could not replicate the intricate amber engravings and bas-relief on the remaining eight pilasters, Rastrelli replaced the amber elements with mirrors mounted in gilded frames to fill the remaining space. This solution created another problem. Russia had no glassmaker capable of making one-piece mirrors more than 3.65 meters in height. This delayed the project for nearly three years, until a French company delivered the mirrors in oak frames at the end of 1745. Martelli also replaced the mirrors in the Dresden frames with oil paintings by Dutch artist Johan van Groot (Gierlowski, 2006a). The Winter Palace room also required an additional amber window frame, so Martelli had to commission an amber workshop in Königsberg to create one. When the window frame arrived, two months before the mirrors, it was discovered that the makers had measured it incorrectly. It took another six weeks to correct the problem (Gierlowski, 2006a).

The Amber Room was completed in late 1745 but was moved again and reassembled in other rooms within the Winter Palace several times before August 1755, when Empress Elizabeth I ordered the entire room to be dismantled a final time and moved about $24 \mathrm{~km}$ (15 miles) out of the city to Tsarskoye Selo, a royal preserve that held the newly constructed palace (also designed by Rastrelli) named for Elizabeth's mother, Catherine I.

The Catherine Palace was one of the largest in Europe. The square chamber selected for the Amber Room was even more spacious than the Winter Palace site and nearly three times the size of the original Prussian cabinet room, despite the fact that one wall consisted mainly of three very large arched windows. The 12 amber panels covered 68.5 square meters and the other elements an additional 5.57 square meters. The wall space of the square room in the Catherine Palace, whose ceiling stood nearly twice as high as the original room, was approximately 216 square meters. And no amber craftspeople who resided in the region possessed the skills to create additional panels.

Rastrelli's goal was to convey the impression that the three walls were composed almost entirely of amber. To occupy the additional space, Rastrelli added 18 mirrored pilasters to separate the amber panels. To account for the ceiling height, he raised the amber panels onto a stone base and placed an elaborate gilded cornice above them. The decorations on the cornice were wreath patterns carved in relief, all coated with gold foil. Above the cornice, Rastrelli commissioned artist Ivan Belsky to paint a simulated amber mosaic on a $30 \times 2.68$ meter canvas. The canvas was mounted over the three non-windowed walls to fill the space between the top of the cornice and the ceiling, creating the illusion that this upper portion was also lined with amber. He painted imitation amber panels to fit in the narrow strips between the double pilasters. Rastrelli also mounted gilded figures, carved reliefs, and gilded bronze candelabras on top of the painting, further obscuring the facade. The wooden panels over the double doors were painted white and covered by gilded reliefs (Gierlowski, 2006a).

To replace the van Groot oil paintings from the Winter Palace amber panels, Rastrelli commissioned Florentine artist and printer Giuseppe Zocchi to create four mosaics depicting the five human senses (sight, hearing, touch, smell, and taste) that would be mounted in the same amber frames as the oil paintings. Craftsmen also created a parquet floor containing 15 different varieties of wood, each a different shade, set in circular motifs (Gierlowski, 2006a).

The basic design was completed in 1756, and Empress Elizabeth began using the room for official functions. However, the many moves had damaged some of the original amber pieces, and she wanted to add amber furnishings to complement the room. Much work was needed before the panels would be completed to her satisfaction.

In 1758 the empress appointed Friedrich Roggenbucke, a noted amber craftsman in Königsberg, to serve as the room's curator and to create amber-covered tables, chests, and bureaus for it. Roggenbucke established an on-site workshop and brought in amber workers from his native city to train local workers, who were mostly recruited from nearby villages. These craftsmen added an amber section over the middle door, replacing a wooden section, and set amber mosaic strips in the narrow sections between the mirrored pilasters and in other small spaces throughout the room (Owen, 2009).

Contemporary reports said that the staff worked long hours (for 12 rubles yearly) because continual repairs were necessary. The palace was not occupied and not heated during the cold Russian winters. When it was occupied, the heat from the 550 wallmounted candles could make the room very warm. 


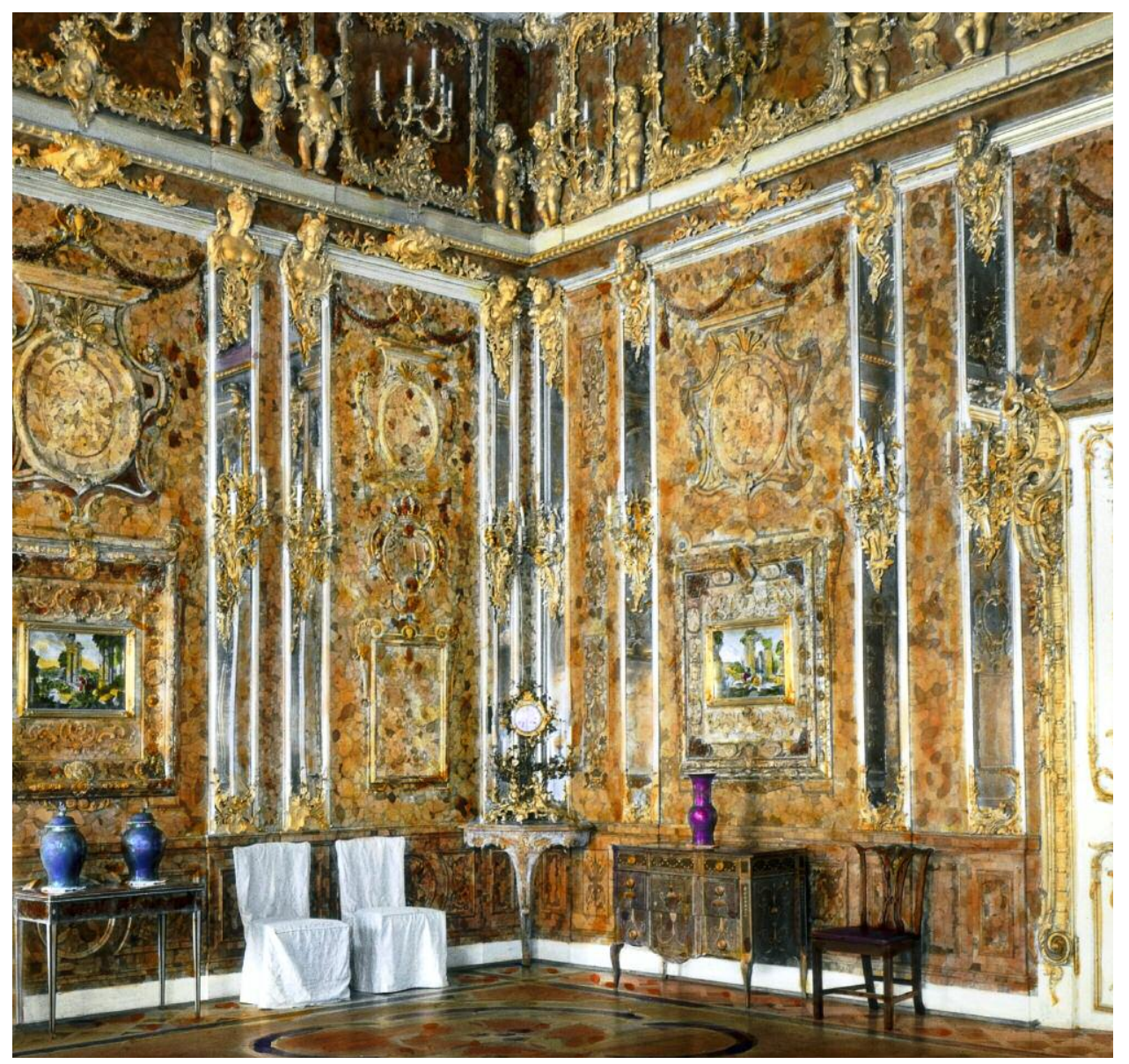

Figure 5. The only known color photograph of the original Amber Room, taken in Tsarskoye Selo in 1937. This photograph helped researchers establish the design and color scheme of the reconstructed Amber Room. Photo courtesy of Amberif.
The extreme changes of temperature and humidity created problems. The temperature-sensitive glue and the wood base expanded or contracted with the changes, causing some of the amber pieces to crack or fall off (Gierlowski, 2006a; Owen, 2009; figure 5).

Besides making continual repairs, the staff constructed a number of amber furniture pieces and small objets to furnish the room. While there was no formal opening ceremony, researchers and historians agree that the main design and construction, other than conservation and repair, was completed in 1780, some 73 years after the project was begun (Gierlowski, 2006a).

\section{THE LOOTING OF THE ROOM}

The Amber Room remained in the Catherine Palace relatively unchanged, except for restorations in 1833, 1865, and 1890. After the Russian Revolution of 1917, the palace was turned into a museum. The room remained intact, though not on public display. Conservation efforts were minimal. In 1937, the Soviet government renamed the town that surrounded the Tsarskoye Selo preserve to Pushkin.
With the invasion by three million German troops in the summer of 1941, Soviet officials began evacuating palace treasures east toward Siberia. As the Germans advanced toward St. Petersburg, the curators of the Amber Room attempted to dissemble and evacuate the panels for safekeeping. But the years had made the amber very brittle, and the pieces crumbled easily, forcing the curators to abandon the effort. Instead, they covered the room with wallpaper veneer in an attempt to disguise the amber (Krylov, 1999).

By September 1941, the German army had advanced to the outskirts of Leningrad and occupied Pushkin and the Catherine Palace. The Amber Room was a priority for removal because it had been included in the Kummel Report, a list of German-made artworks to be "repatriated" to German soil (Owen, 2009). The German army dismantled the room panels and decorations within 36 hours, packing it in 27 crates, and shipped it by rail to Königsberg, where it was reassembled and displayed in the city's castle (Krylov, 1999). Two years later, museum director Dr. Alfred Rohde was ordered to dismantle the room again and crate it in the event that British or U.S. 
bombers attacked the city. The room panels were last seen January 12, 1945, when Dr. Rohde wrote that the amber panels were being crated. "As soon as it is done, I shall evacuate the panels to Wechselberg near Rochlitz in Saxon" (Owen, 2009). By then the Allied air raids on Königsberg had already begun, though the castle had remained intact. The air raids eventually destroyed most of Königsberg Castle, leaving the outer walls and some battlements. In the spring of 1945 , Soviet troops advanced into the city and leveled the remainder of the castle.

Immediately following the war, the Soviet government made finding the Amber Room a priority. It seized the territory of East Prussia as a Russian province (including Königsberg, renamed Kaliningrad in 1946), and soon afterward dispatched a group of investigators to search the ruins of the castle. They located several items of furniture from the Catherine Palace in an intact tower and, the following year, discovered the ruins of three of Giuseppe Zocchi's Florentine mosaics from the room (Owen, 2009; figure 6).

While there have been numerous theories about the fate of the Amber Room, the only certainty is that it disappeared between the time of the German

Figure 6. This photo, purportedly taken by a German soldier, shows the destruction of the Catherine Palace during the German siege of St. Petersburg in World War II. The panels from the Amber Room were seized by the German army at the beginning of the siege and transported to a castle in Königsberg for display. They were never recovered after the war. Photo courtesy of REX/Shutterstock.com.

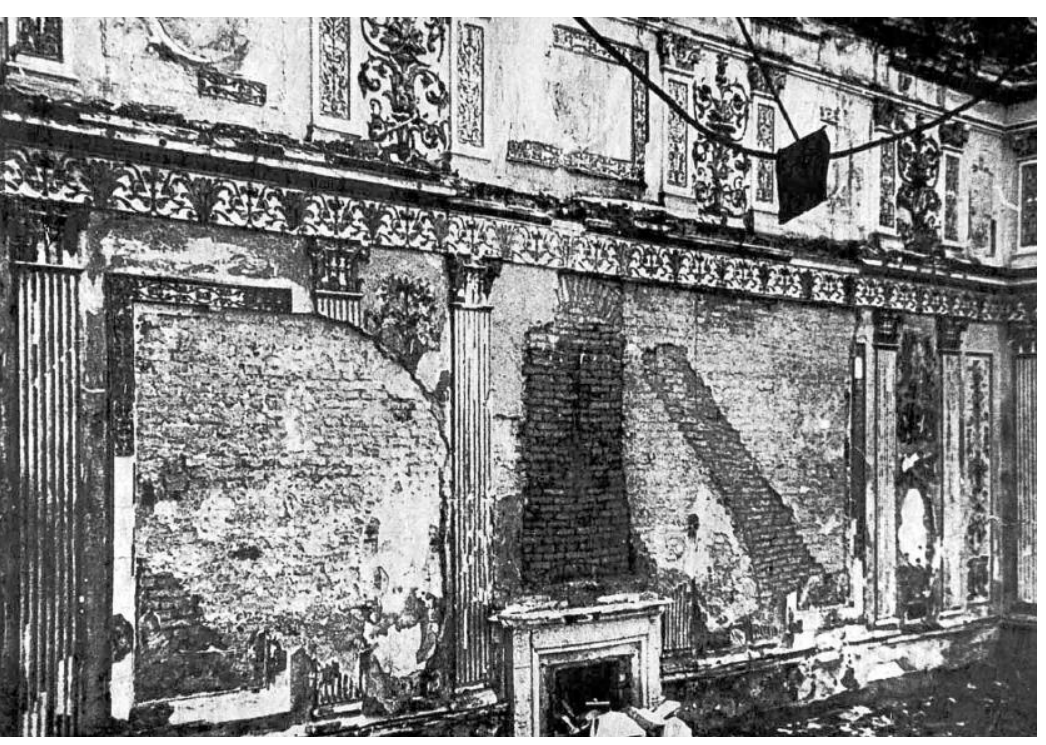

invasion in 1941 and the arrival of the Soviet troops in Königsberg in 1945. Erich Koch, the SS commander who had ordered the removal of the amber panels from the city, reportedly led a group of Russian officials on a search during the 1950s but failed to find them. He died in 1986 without ever providing additional information (Grimaldi, 1996; Blumberg, 2007). In 1967, the Soviet government formed a commission to systematically search known art repositories in the USSR and Germany for the Amber Room panels. The commission continued the search until 1984, five years after the decision was made to recreate the room (Owen, 2009).

Most historians believe that the Amber Room was destroyed by Allied bombing raids on the castle after January 1945 or the subsequent Russian invasion and shelling of the city. One museum conservator, an amber expert, noted that the panels, if ever discovered, would be too deteriorated to be of any use today (Varoli, 2000). Since the war's end, numerous parties have appeared from time to time claiming, without substantiation, to have found the missing amber panels. Most recently, in October 2017, a group of treasure hunters claimed to have located them behind the doors of a Polish bunker (Wight, 2016; "Amber Room: Priceless Russian treasure...", 2017).

While the room panels have never been found, some pieces of the original have surfaced over the years, most importantly one of the Zocchi mosaics, "Touch and Smell." The ruins of the other three mosaics were found in the destroyed Königsberg Castle in 1945, and this piece had been considered lost until then. It was offered for sale by Meinhardt Kaiser to an antiques dealer in Bremen, Germany, in 1997. The dealer alerted police, and Kaiser led them to a man named Rudi Wurst, whose father had been part of the SS unit that escorted the train carrying the Amber Room components from the Catherine Palace to Königsberg in 1941. Police believe that this piece had been long separated from the rest of the room's treasures. Locating it helped the restorers achieve much greater historical accuracy in their recreation (National Geographic, 2004; Owen, 2009; A. Krylov, pers. comm., 2017).

\section{THE RECONSTRUCTION}

The end of World War II left the entire Catherine Palace in ruins. An exhibit of wartime photographs (Tsarskoye Selo State Museum, 2013) shows part of the palace ablaze and some interior images of the ruined structure. A photograph purported to be of the 
Amber Room shows the walls completely stripped to bare brick, except for fragments of the paintings above the cornice. The roof is collapsed, leaving the room exposed to the elements.

In the 1950s, the Soviet government embarked on a project to restore this and other historical sites destroyed and damaged during the war. Reconstruction took 25 years, and the Catherine Palace was reopened to the public in the summer of 1980 . The Amber Room, however, had only been minimally renovated. The imitation amber mosaic painting over the cornices had been redone, and the parquet floors, decorated ceilings, and mirrored pilasters were all restored as closely as possible to the original designs. The walls, however, remained unadorned (Zhuravlov, 2006). The empty walls were temporary; in April of the previous year, the Federal Council of Ministers had issued an order to begin reconstruction of the panels for the Amber Room (Gierlowski, 2006a). The mandate was to recreate the room as closely as possible to the design completed in the eighteenth century. The challenge was formidable since very little documentation of the original room existed. Available resources included:

- Eighty-six black-and-white photographs of the room, taken in the late 1930s for a planned restoration.

- A single color slide of one section of the room, from 1937. The slide showed the southwest corner and included two of the mosaics, their frames, six mirrored pilasters, the statues, candelabras, and the gilding around the cornice. The slide provided some information on how various colored pieces of amber were assembled on the walls in irregular but aesthetically pleasing patterns.

- Seventy-six amber fragments found in the destroyed room. Some were pieces of wall decorations and chips from amber carvings. These gave researchers information on the thickness and hues of the amber pieces used on the walls.

- A miniature chest assembled with amber, dating from the time of the Amber Room construction, which survived in the Catherine Palace collection but was in very poor condition (Krylov, 2006). While working on its restoration, the team found the signature of Gottfried Turau. Thus, the team had an opportunity to study firsthand the techniques of one of the room's creators (Gierlowski, 2006b).
- The curator of the Amber Room from 1916 to 1941, Anatoly Kuchumov, who was still alive and able to help plan the reconstruction.

Other than the amber itself and the oak frames and base, no one knew the composition of the other materials employed in the frames and adhesives ( $M$. Trutanova, pers. comm., 2017).

With so little to guide them, several years of research were necessary before the reconstruction could begin (M. Trutanova, pers. comm., 2017). The research team, assembled two years before the decision to begin the reconstruction, was composed of Alexander Krylov, Alexander Zhuravlov, and three other graduates of the Mukhina Academy of Arts and Design at Leningrad State University (now St. Petersburg State University). They began by studying other amber objects that had been removed from the Catherine Palace well before the German invasion, examining the few amber objects that had been removed from the palace and hidden in a Siberian bunker just prior to the invasion. In addition, the research team assembled all the documents on seventeenth- and eighteenthcentury amber craft they could locate, including an original drawing by Andreas Schlüter from 1701 (Krylov, 1999). They enlarged and enhanced the grainy 1930s photographs to reveal shadings and grayscales that would offer clues to color patterns of the amber mosaics and details in the carvings (Owen, 2009).

Each piece was cleaned thoroughly and photographed on a white background. They were matched against similar pieces located in the photographs, which allowed the team to match the actual color in the reconstructed elements (Krylov, 2006).

The researchers tested what they had learned from restoring and reconstructing other amber objects such as furniture and sculptures that resided in the Hermitage Museum and Pavlovsk Palace, both in St. Petersburg, and the Oruzheynaya Palace in Moscow. Between 1979 and 1984, the team, which included Zhuravlov and Krylov, recreated a number of historical pieces. Among these were a chessboard with 32 carved figures, the original of which was made in Germany in the eighteenth century and housed at the Hermitage; a casket bearing a figure of the Greek goddess Dione, also from the Hermitage, that was made in Danzig in the seventeenth century; a large cameo with a likeness of Empress Elizabeth from the Amber Room; and six amber obelisks from Pavlovsk (Zhuravlov, 2006). To test their techniques, they created a model panel of the Amber Room from simulated amber (Owen, 2009). 
It took three years from the official approval before the room reconstruction could begin in earnest. The Restavrator, the team that would perform all of the reconstruction work, was formed in 1982. Headed by Boris Igdalov and including Marina Trutanova, they commenced work in a studio in St. Petersburg (Zhuravlov, 2006). The distance between St. Petersburg and Pushkin would allow the work to be kept secret (Owen, 2009).

Much research remained, however. First, the teams investigated the wood to use for the baseboards and the adhesives to hold the amber pieces in place. For the baseboards, the restoration team decided to use pressure-treated pine rather than the oak used in the original, because it would be less likely to absorb moisture or expand and contract with changes in temperature and humidity. The foil backing chosen for the amber was brass instead of bronze (M. Trutanova, pers. comm., 2017).

To determine the makeup of the adhesive, the research team submitted several of the surviving pieces of amber to the Leningrad Institute of Criminal Investigation. Through spectroscopic analysis, the Institute found that the adhesive consisted of $40 \%$ beeswax and $60 \%$ dammar resin, a gum from the Dipterocarpaceae family of trees in India and East Asia that was used for ship caulking at the time the original room was constructed (Zhuravlov, 2006). Determining the correct adhesive was more than a matter of historical accuracy. Permanent adhesives were not suitable because they would have prevented the replacement of amber pieces broken during the reconstruction process or in future repairs or restorations. In addition, permanent adhesives would likely crack over time (M. Trutanova, pers. comm., 2017).

Using the crime lab's findings as a guide, the reconstruction team developed an adhesive from beeswax and a type of pine resin that melted at about $140^{\circ} \mathrm{F}\left(60^{\circ} \mathrm{C}\right)$. This combination allowed workers to use a commercial hair dryer to apply or remove amber pieces. The research team tested this and other adhesives, subjecting them to heat /three hours at $\left.40^{\circ} \mathrm{C}\right)$, cold $\left(2.5\right.$ hours at $\left.-15^{\circ} \mathrm{C}\right)$, ultraviolet light (2.5 hours), and a high-moisture environment (14 hours) (M. Trutanova, pers. comm., 2017; A. Zhuravlov-Nikiforova, pers. comm., 2017). Next was acquiring the amber. The research team estimated that the reconstruction would require $6,000 \mathrm{~kg}$ of "bestquality" amber. The wall areas measured 86.12 square meters. The decorative objects and motifs would require an additional 122 square meters of ma- terial. The average thickness of each piece of amber was planned at $5 \mathrm{~mm}$, similar to the original (Zhuravlov, 2006).

With the approval of the Soviet government, the reconstruction team was given access to the amber deposits in the Sambia Peninsula, which were then under state control. While the amount of amber required for the reconstruction was substantial $(6,000$ $\mathrm{kg}$ or 3 metric tons), production in the Samland region was much higher, ranging between 595 and 744 metric tons yearly from 1979 to 1988 (KosmowskaCeranowicz, 2006).

With supplies assured by the Soviet government, the workshop team began researching dyes and treatments that would have been used in the eighteenth century to recreate the yellow to reddish orange patterns on the original walls. No one knew what materials were used for the original dyes, so a team from the Leningrad Institute of Technology developed dyes that would not fade, change color, or fully absorb into the amber (Gierlowski, 2006b). While the ingredients used in the dyes are proprietary, the process involves immersing the amber into boiling water for $10 \mathrm{~min}$ utes, with the appropriate dyes added afterward $(M$. Trutanova, pers. comm., 2017). However, a division developed among researchers between those who wanted to employ natural-color amber and those who wanted to dye the material to the darker shades it had assumed by the time the 1937 color slide was taken. Ultimately, the latter group prevailed (Gierlowski, 2006a).

Before dyeing, the amber to be mounted on the wall in mosaic patterns was sliced to $3 \mathrm{~mm}$ thick instead of the planned $5 \mathrm{~mm}$ - presumably a cost reduction - and then fitted onto the wood panel without adhesive. The reconstruction team then numbered each piece and dyed them the appropriate colors ( $M$. Trutanova, pers. comm., 2017). Not all of the reconstruction followed eighteenth-century techniques. Some of the amber was treated at high pressure and temperature to improve its translucency and match the colors from the original room. The material was placed in pressure chambers filled with nitrogen or argon, and then heated to $300^{\circ} \mathrm{C}$. In other cases, pressed amber-material left over from carvings or cuttings, ground into powder, and pressed into the appropriate shapes before dyeing - was used in the reconstruction (Gierlowski, 2006b). In all, 4.2 square meters of pressed amber was used in the wall panels.

The amber mosaics lining the wall panels were only the beginning of the reconstruction. The ornate decorative motifs such as scrolls, wreaths, laurels 


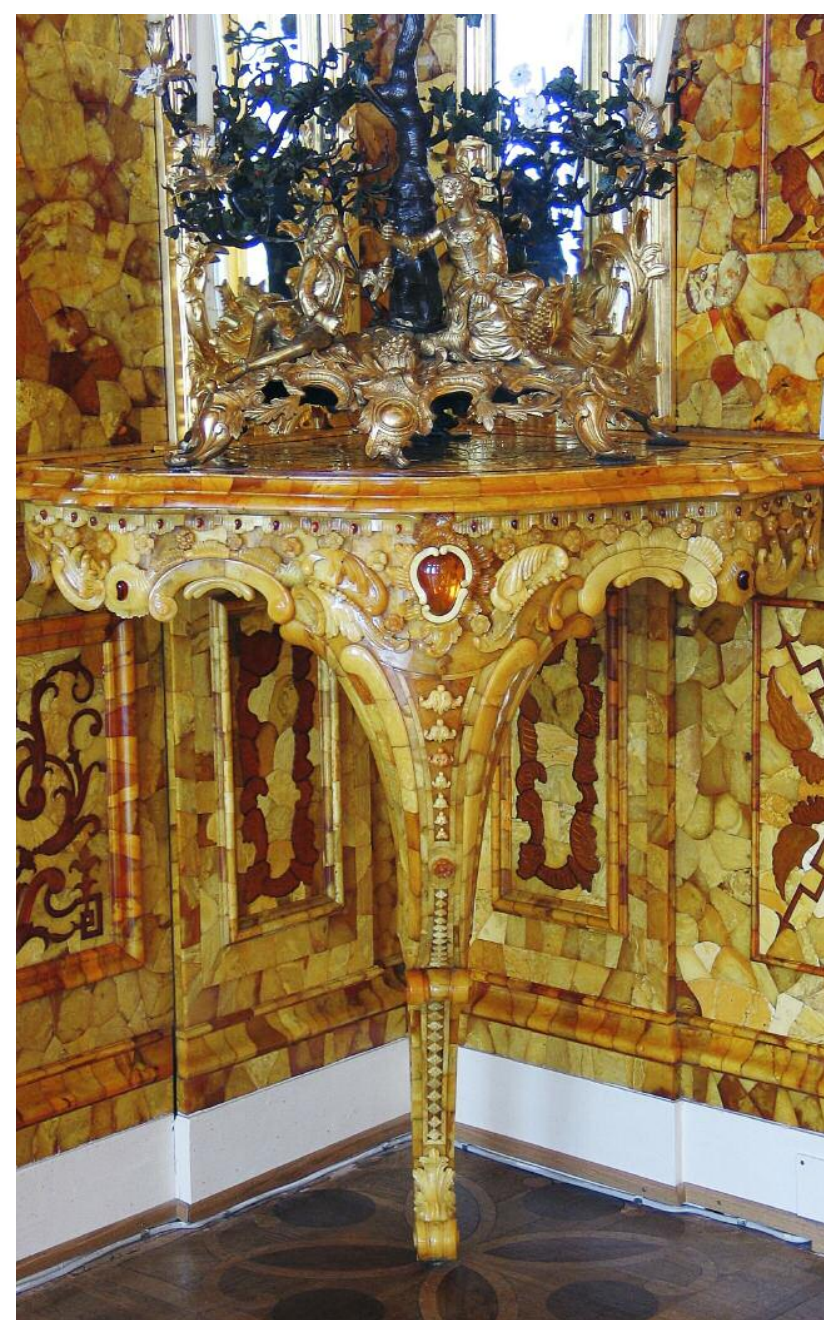

Figure 7. A corner section and end table showing the detail of the multi-hued recreated amber mosaics, the bas-relief employing darker shades of amber, and the table itself, which is also coated with amber. Photo courtesy of Amberif.

(which used the darkest-colored pieces), floral bas-reliefs, and objects such as grotesques and other sculptures were all made from carved amber. While the carving and assembly skills required were transferable from jewelry and sculpting crafts, they proved extremely time-consuming (Krylov, 2006; figure 7). Working from the black-and-white photos, the workshop recreated the destroyed Zocchi mosaics of the senses using jasper, malachite, quartz, chalcedony, and nephrite.

The comparison with the recently discovered Zocchi mosaic in Bremen validated their reconstructive work, which was nearly identical to the original.
The only exception was in the materials-the original contained various colored marble slices instead of the decorative stones used by the studio (Krylov, 2006). The original mosaic is kept in storage at the palace but put on display for significant occasions (M. Trutanova, pers. comm., 2017; see figures 8-10).

After the collapse of the Soviet Union in 1991, the Russian government could no longer fund the project, and work was nearly suspended with fewer than $40 \%$ of the panels completed (Varoni, 2000). The Restavrator studio, which numbered about 50 artisans, was liquidated, though some work continued. Up to that point, the government had spent the equivalent of US $\$ 7.85$ million on the reconstruction-largely on salaries since the amber had been provided as a state

Figure 8. A craftsman in the Tsarskoye Selo Amber Workshop completing a carving for the mosaic "Touch and Smell" from slices of jasper, malachite, quartz, chalcedony, and nephrite. Photo courtesy of Tsarskoye Selo Amber Workshop.

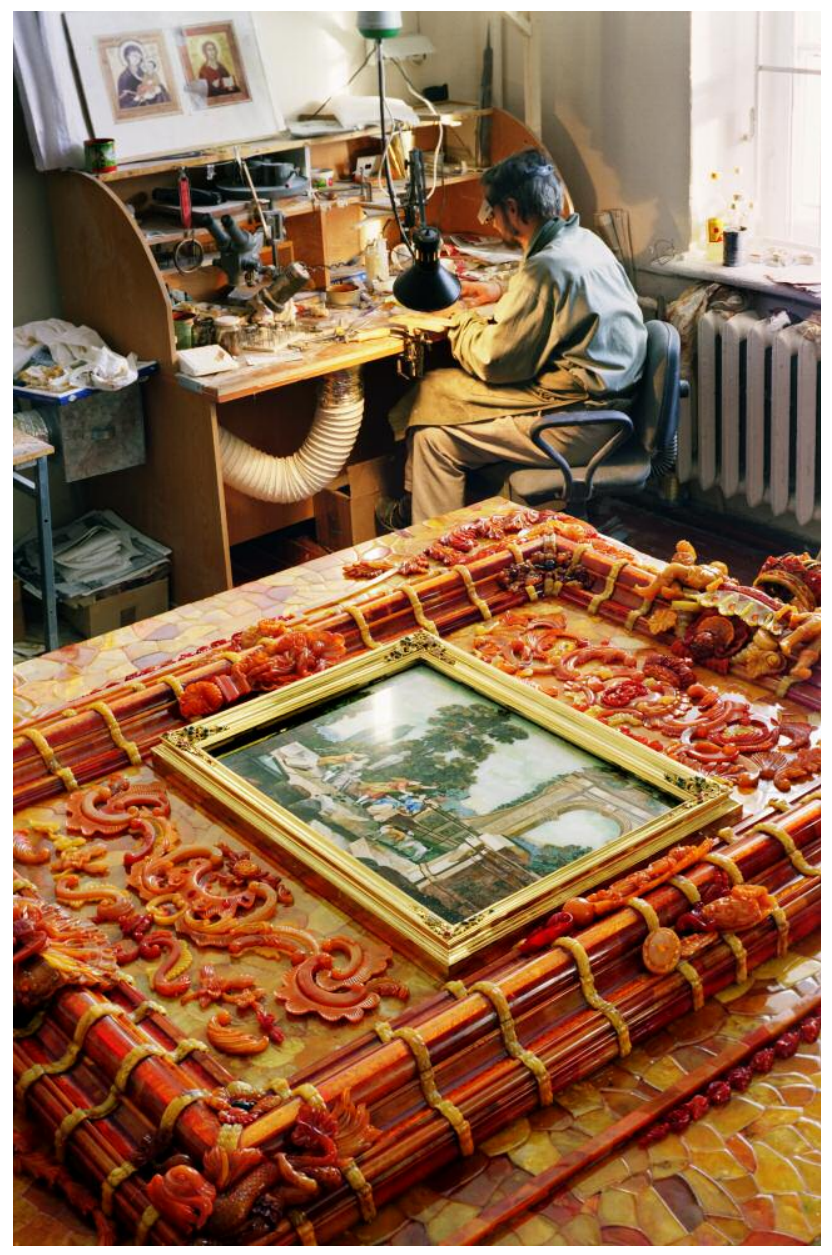




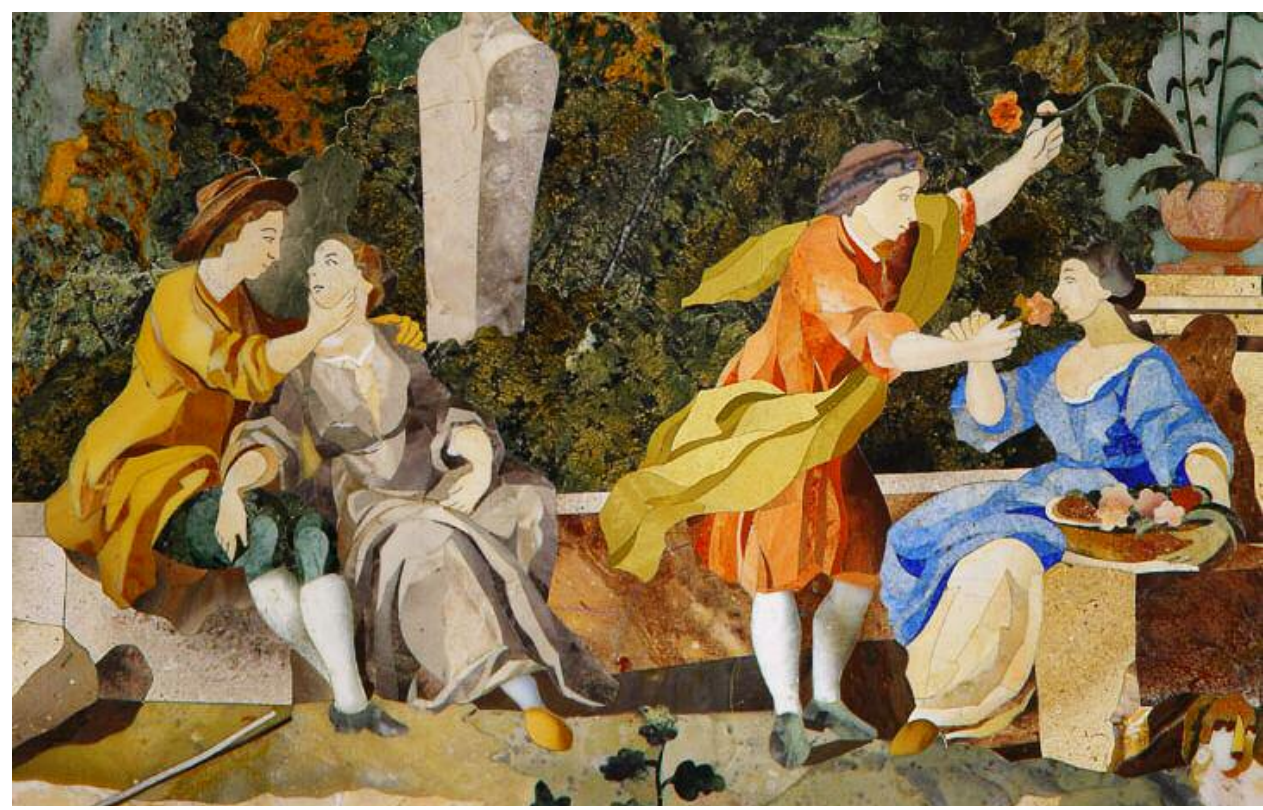

Figure 9. Detail of the original "Touch and Smell" mosaic panel made from colored marble pieces. The panel was apparently stolen by a German officer as the contents of the Amber Room were being evacuated from Königsberg Castle in 1941. It was discovered in Bremen, Germany, in 1997. Photo courtesy of Tsarskoye Selo Amber Workshop.

resource (A. Zhuravlov-Nikiforova, pers. comm., 2017). The new market economy meant that instead

Figure 10. Detail showing the Florentine mosaic "Sight," one of four such recreated mosaics in the room. The frames are fashioned from carved and sliced pieces of amber of various hues. Photo courtesy of Amberif.

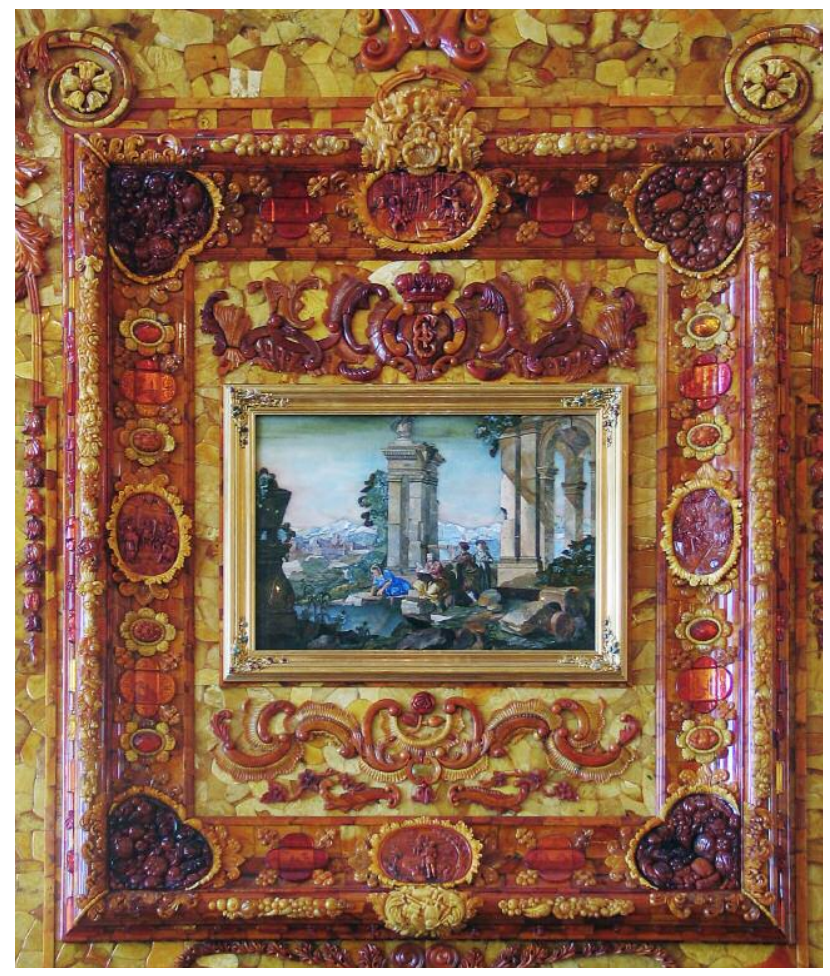

of relying upon the Russian government for funding, the company had to raise funds from private sources (Gierlowski, 2006b).

Through the intercession of Dr. Burkhart Gores, the director of the Prussian Palaces and Gardens Foundation, funding was obtained in 1999 from the German energy company Ruhrgas, which had extensive dealings in Russia (Owen, 2009). Ruhrgas agreed to provide an additional US\$3.5 million to complete the reconstruction and ordered its completion by April 2003. Ruhrgas chairman Friedrich Spath told the New York Times, "The Amber Room has enormous emotional significance for both Germany and Russia. And it is a leading symbol of a time when close German and Russian relations were a model for the world." At that time, Ruhrgas was receiving one-third of its natural gas supplies from Russia (Varoli, 2000).

With new funding, the Restavrator reorganized into a corporation named the Tsarskoye Selo Amber Workshop to resume its work full time and complete it by the contracted deadline. The new company also began earning income by manufacturing and selling amber carvings, miniature chests, and chess sets that resembled historical pieces, and taking commissions to restore or reconstruct other amber pieces in museums. This, along with the use of synthetics, raised objections from some members of the research team who felt they were acting against the Venice Charter of 1964, which forbids the use of contemporary techniques and materials and "conjecture" in reconstructing historical monuments (Gierlowski, 2006b; Owen, 2009). 


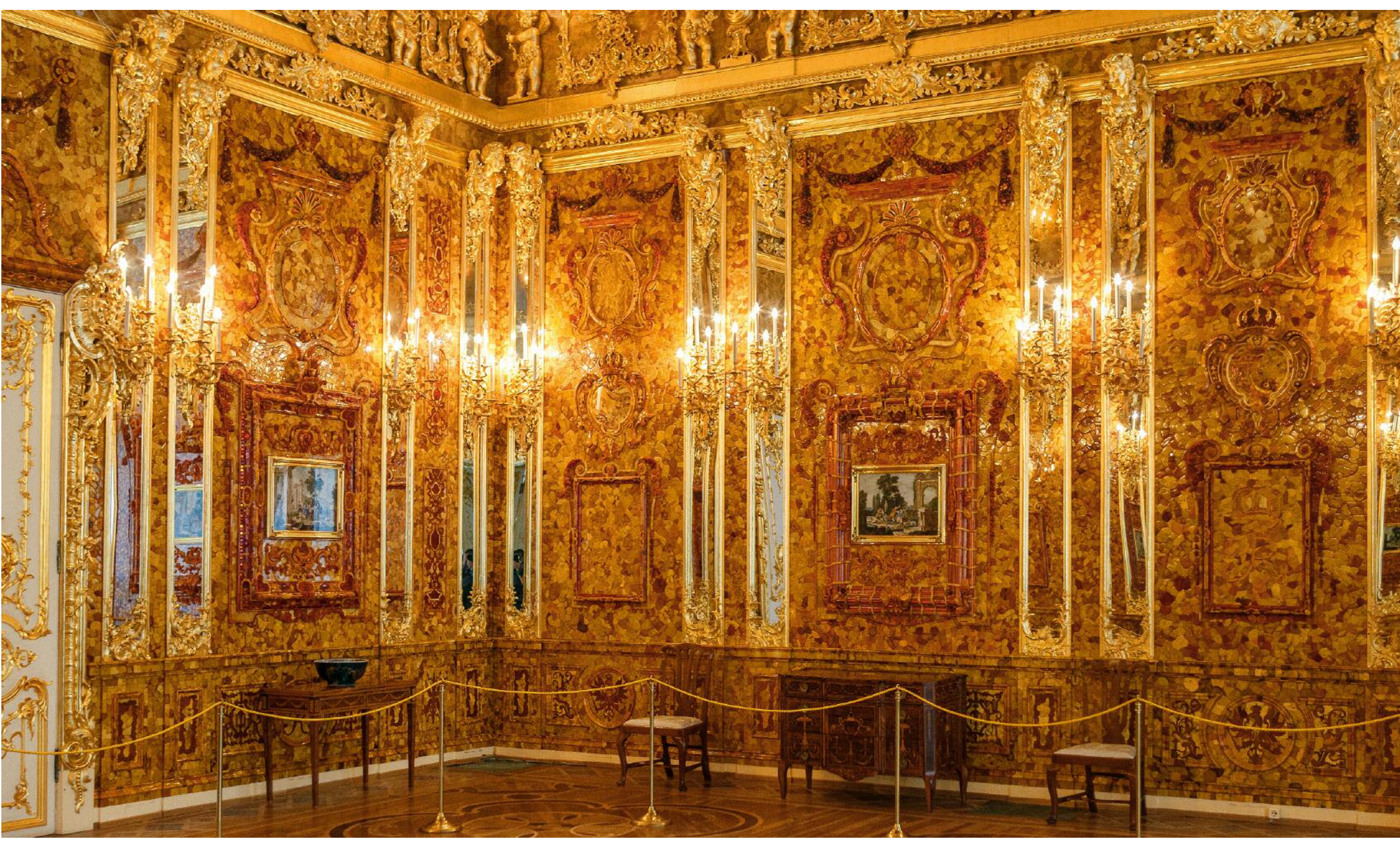

Figure 11. Two sections of the reconstructed Amber Room wall showing the mirrored pilasters that separate the panels, the Florentine mosaics, and the intricate amber wreaths and clusters on and atop the cornice. Photo by Sergey Bogomyako/Shutterstock.com.

The completed room used some 100,000 pieces of amber encompassing more than 150 square meters of wall space. While the design was as faithful as possible, some who remembered the original Amber Room believed the reconstructed room was brighter, though others countered that the varnishes used on the amber surfaces in previous repair and restoration efforts had darkened over the years (Owen, 2009; see figures 11 and 12).

In May 2003, as the city of St. Petersburg celebrated its 300th anniversary, a summit of world leaders-including Russian President Vladimir Putin, German Chancellor Gerhard Schroeder, U.S. President George W. Bush, French President Jacques Chirac, British Prime Minister Tony Blair, Italian Prime Minister Silvio Berlusconi, and Japanese Prime
Minister Junichiro Koizumi-formally opened the reconstructed Amber Room to the public. According to saint-petersburg.com, the tourist attraction receives about 7,000 daily visitors during the peak summer months.

The Tsarskoye Selo Amber Workshop remains on site for ongoing maintenance because the temperature-sensitive adhesives require constant attention. Amber itself is called a "living stone" that can react to relatively small changes in temperature and humidity. Inspectors check the room weekly (After the Amber Room, 2013). Other rooms in the Tsarskoye Selo complex are also undergoing reconstruction, including the church, the Agate Room, and the Catherine Palace Museum, as well as restoring amber artifacts in other Russian museums. In addition, the 


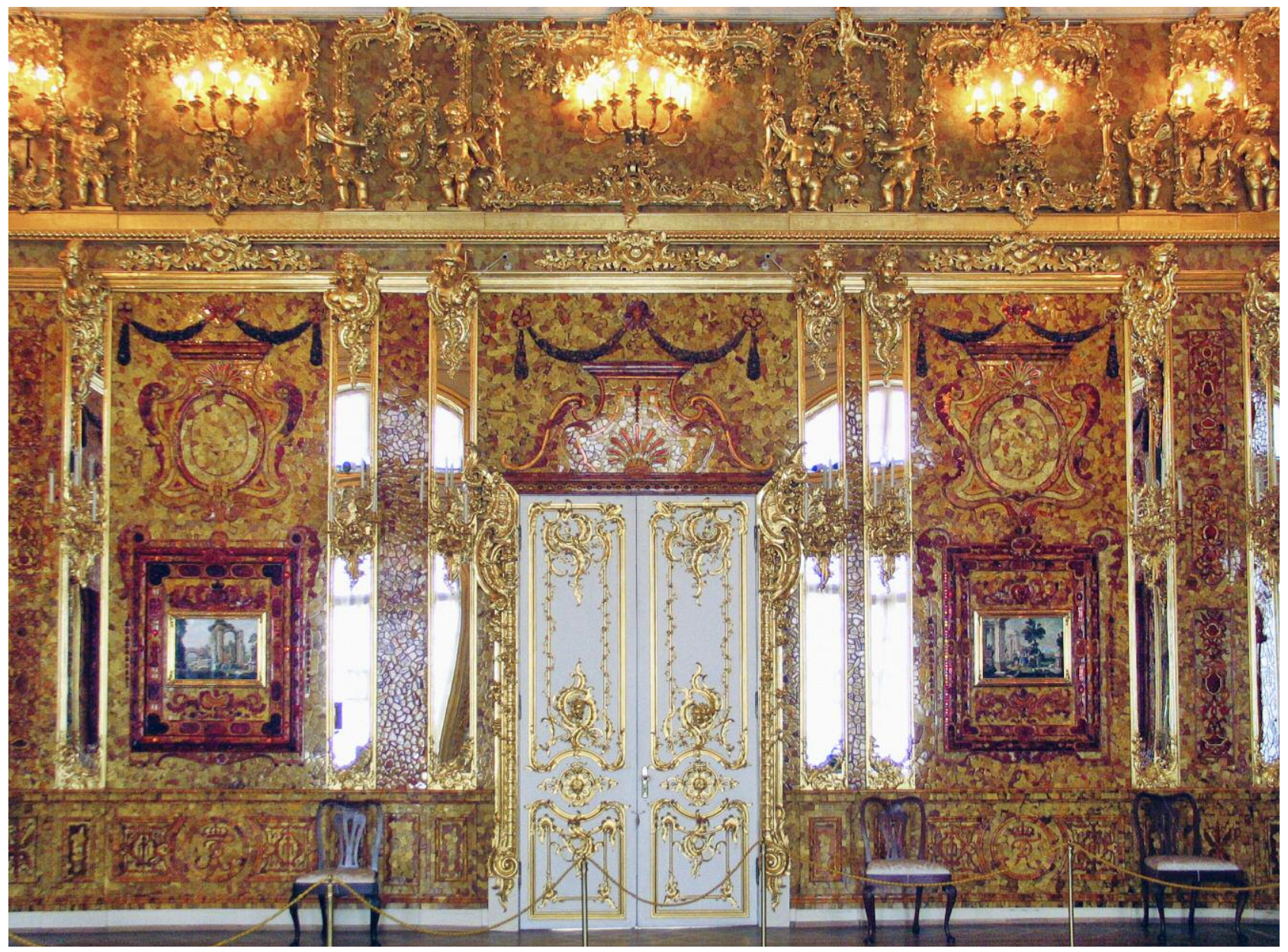

Figure 12. A section of the wall of the reconstructed Amber Room. Photo courtesy of Amberif.

studio continues to produce amber objects for sale to help offset the high costs of maintaining the Amber Room.

\section{CONCLUSIONS}

Although many articles have been written about the original Amber Room, few have documented its reconstruction, and fewer still have offered detailed accounts of both the original and reconstructed rooms. Its reconstruction was fraught with a number of chal- lenges, but the result is regarded as being faithful to the version of the Amber Room that was housed in the Catherine Palace from 1780 to 1941. Firsthand accounts from the principal researchers, designers, and builders of the reconstructed room describe a combination of eighteenth-century techniques, many of which had to be relearned or adapted to modern materials, offering insight into the significant challenges encountered to reconstruct this cultural landmark.
ABOUT THE AUTHOR

Mr. Shor is a senior industry analyst at GIA in Carlsbad, California.

\section{ACKNOWLEDGMENTS}

The author would like to thank Ewa Rachon, project director at Amberif and Amber Mart (Gdansk, Poland), who provided introductions and offered valuable insights for the manuscript; Alexan- der Krylov, an amber craftsman who helped design the reconstruction; and Anastasia Zhuravlev-Nikiforova, who provided some of her father's, Alexander Zhuravlov's, papers on the reconstruction of the room. Boris Igdalov and Marina Trutanova of the Amber Workshop (Tsarskoye Selo) are thanked for sharing their research and invaluable expertise. 


\section{REFERENCES}

After the Amber Room: History of the Tsarskoselskaya Workshop (2013) Avrora-Design, St. Petersburg.

Amber Room: Priceless Russian treasure stolen by Nazis "discovered" by German researchers (2017) www.independent.co.uk/ news/world/europe/amber-room-nazis-russian-catherinepalace-st-petersburg-tsar-second-world-war-stolen-treasurea8008526.html

Blumberg J. (2007) A brief history of the Amber Room. Smithsonian.com, https://www.smithsonianmag.com/history/a-briefhistory-of-the-amber-room-160940121/

Butrimas A., Jovaiša E. (2013) The Balt's amber route to classical civilization. Paper presented at International Amber Researcher Symposium, March 20-23.

City of Gdansk (2017) Gdansk treasures - amber. www.gdansk.pl/ en/about-gdansk/Gdansk-treasures-Amber,a,3019

Clark N.L.D (2010) Amber: Tears of the Gods. Dunedin Academic Press, Edinburgh, pp. 23-28.

Czebreszuk J., Szmyt M. (2013) Amber in Europe 3000 Years BCE. Paper presented at International Amber Researcher Symposium, March 20-23.

Gaigalas A., Halas S. (2009) Stable isotopes $(\mathrm{H}, \mathrm{C}, \mathrm{S})$ and the origin of Baltic amber. Geochronometria, Vol. 33, No. 1, pp. 33-36, http://dx.doi.org/10.2478/v10003-009-0001-9

Gierlowski W. (2006a) Amber Room - the founders and creators. In B. Kosmowska-Ceranowicz and W. Gierlowski, Eds., Amber: Views, Opinions. Scientific Seminars: AMBERIF-1994-2005. International Amber Association, Gdansk, Poland, pp. 147155.

(2006b) Reconstruction of the Amber Room as an impulse for the creation of copies and reconstructions of lost historical artifacts. In B. Kosmowska-Ceranowicz and W. Gierlowski, Eds., Amber: Views, Opinions. Scientific Seminars: AMBERIF-1994-2005. International Amber Association, Gdansk, Poland, pp. 165-172.

Grimaldi D.A. (1996) Amber: Window to the Past. Harry N. Abrams Inc. in association with the American Museum of Natural History, New York, pp. 147-191.

Hein J. (1991) Ivories by Gottfried Wolfram. Scandinavian Journal of Design History, Vol. 1. pp. 7-34.

Kosmowska-Ceranowicz B. (2006) Finds, deposits and mines of amber and other fossil resins. In B. Kosmowska-Ceranowicz and W. Gierlowski, Eds., Amber: Views, Opinions. Scientific Seminars: AMBERIF-1994-2005. International Amber Association, Gdansk, Poland, pp. 9-13.
24.

Krylov A. (1999) Reconstructing the amber masterpiece. Paper presented at International Amber Research Symposium, March $23-24$.

(2006) Reconstructing the Amber Room. Selected problems. In B. Kosmowska-Ceranowicz and W. Gierlowski, Eds. Amber: Views, Opinions. Scientific Seminars: AMBERIF1994-2005. International Amber Association, Gdansk, Poland, pp. 160-162.

Langenheim J.H. (1990) Plant resins. American Scientist, Vol. 78, No. 1., pp. 16-24

Mazurowski R. (2011) From the research on the Late Neolithic amber art in the Neidzwiedziowka microregion near Nowy Dwor Gdanski (3100-2400 BCE) Session of the World Amber Council, May 27-28. http://prusaspira.org/pogezana/Bursztyn.pdf

National Geographic (2004) The mystery of the Amber Room. https://video.nationalgeographic.com/video/treasurewars/amber-room-tw

Netzer S. (1993) Bernsteingeschenke in der Preussischen Diplomatie des 17 Jahrhunderts. Yearbook of the Berlin State Museum, Berlin, pp. 227-246.

Owen J. (2009) Forever amber: The impact of the Amber Room on Russia's cultural stature then, now and in the future. Master's thesis, Georgetown University, Apr. 27, https://repository. library.georgetown.edu/bitstream/handle/10822/552838/ owenJennifer.pdf

Tsarskoye Selo State Museum (2013) The loss of the palaces: Tsarskoye Selo in 1941-1944. http://eng.tzar.ru/shows/show/ archive/?id=3142

Varoli J. (2000) Amber Room, lost to war, is recreated. New York Times, Jan. 23, https://www.nytimes.com/2000/01/23/arts/artarchitecture-amber-room-lost-to-war-is-recreated.html

Wight E. (2016) Is 60-year hunt for the missing \$400million Amber Room finally over? Daily Mail, Apr. 22, http://www.dailymail. co.uk/news/article-3552241/Is-60-year-hunt-missing-250million-Amber-Room-FINALLY-New-images-Nazi-looted-treasure-hidden-sealed-wall-secret-room-underground-bunker-Pola nd.html

Zhuravlov A. (2006) Amber Room - Beginning the reconstruction. In B. Kosmowska-Ceranowicz and W. Gierlowski, Eds., Amber: Views, Opinions. Scientific Seminars: AMBERIF-1994-2005. International Amber Association, Gdansk, Poland, pp. 155162

\section{For online access to all issues of GEMS \& GEMOLOGY from 1934 to the present, visit:}

